\title{
YOUNGERS FOR YOUNGERS: PIER GIORGIO FRASSATI AND VALERIU GAFENCU TWO EXAMPLES OF MISSIONARIES AMONG YOUNG PEOPLE IN CONTEMPORARY TIMES
}

VeSA Benedict (VALENTIN)*

Abstract: 2016 was dedicated by the Synod of the Romanian Orthodox Church to the education of the young people. In this frame, one may find important to focus on some young characters that, by their endeavour, can indicate a missionary methodology among this segment of people, in particular, one from the western Church, Pier Giorgio Frassati, and another one from the Eastern Church, Valeriu Gafencu, both of them important names in the missionary realm of the last century. This paper aims to focus on two moments - a missionary bio-bibliography of the two characters and the identification of a list of constants as reflected in their missionary activity. Finally, one is interested to identify some general indicators for the missionary activity among contemporary young generation.

Keywords: mission, young missionary, faith, spiritual life, Pier Giorgio Frassati, Valeriu Gafencu.

In contemporary times, in the ecclesiastic missionary field, one often emphasises the necessity of the pastoral work with the young people. One finds this necessary for the contemporary landscape shows that the majority of people attending the divine service is formed of mostly persons from 40 years old onwards and, eventually, children under 15 years old. And it seems that the segment of young people, from 15 up to 35 years old, is not very present and active in the parish life. If up to last century, one could still identify a natural transmission of faith in the family, at school, as well as local parish, nowadays this paradigm is not really present so much. This is why one needs a special catechetic program for young people and, in consequence, a special pastoral care for this category of faithful.

\footnotetext{
* Assistant lecturer Babeș-Bolyai University, Cluj-Napoca (ThD, Babeș-Bolyai University, Cluj-Napoca; $\mathrm{PhD}$, University of Padua, Italy).
} 


\section{Young people and Christian education}

There are different programs ruled for the young people in the parishes as well as organised at the national or international level. The actuality and immediacy of the catechetic education of this age segment comes out also from the historical and social context, in particular, the problem of immigrants in Europe, mostly of other faiths than Christians. This leads, in my opinion, to the necessity of having a Christian formation, as European culture, ecclesiastical or secularised, without any doubt, is based on Christian fundaments. In consequence, so that to have a dialogue and, finally, a communication with other faiths, one firstly needs to be aware and informed about its own faith, even if considered simply as a historical factor in building the society to which he belongs to, lacking any inner personal relevance. The thesis that I would like to emphasise in this paper is the necessity of Christian education for an equilibrate attitude of dialogue with other faiths. One needs to have a clear identity so that to enter into a constructive relation with what means "the other", a concept very specific for contemporary times.

In this context, one specific methodology gets a plus of importance - the paradigm of examples. This presupposes and aims to identify representative characters among the Youngers that ruled missionary activity within the same social category in contemporary times. This is why in the title I have highlighted the expressions "Youngers for Youngers". I have chosen two young persons from two different areas who clearly have one thing in common - they were missionary agents of the moral life within the segment of young people in the last century. One of them belonged to the Western branch of Christianity, Pier Giorgio Frassati, a courageous student, defender and witness of the hope among the students of Turin at the beginning of the $20^{\text {th }}$ century $^{1}$, and the other one to the Eastern

\footnotetext{
${ }^{1}$ Patron saint for millions of youth around the world. For a detailed biography see Luciana Frassati, A Man of the Beatitudes: Pier Giorgio Frassati, Ignatius Press, 2000; Maria de Lorenzo, Blessed Pier Giorgio Frassati, an Ordinary Christian, Pauline Books, 2004; Robert Claude, The Soul of Pier Giorgio
} 
Church, Valeriu Gafencu ${ }^{2}$, a witness of confessing Christian faith during the terrible communist persecution in Romania. Regarding the historical and religious context, despite the fact they are quite different, one may identify some common constants that aimed their missionary activity among young people.

This paper is divided into two moments: firstly I will evoke a short missionary biography of the two authors, including summary information of the historical and religious context and then I will try to identify some missionary principles that stood at the very base of their activity among the young contemporary people. The conclusion of the paper aims to picture two possible personages and, in consequence, two itineraries capable to being examples and models for the youngers in matter of assuming a missionary Christian faith, with reference to the contemporary situation: on one side the western religious relativism and indifferentism, and, on the other side, the religious fundamentalism and activism that comes from the Islamic world.

\section{Pier Giorgio Frassati - a missionary sportsman}

At the beginning of the World Youth Day at Cologne in 2005, Pope John Paul II, being very conscious of the necessity of renewal of the Church by the means of an active and enthusiastic missionary activity among and with the young people, urged those gathered there on this occasion: "Dear young people, the Church needs genuine witnesses for the new evangelisation: men and women whose lives have been transformed by meeting with Jesus, men and women who are capable of communicating this experience to others. The Church needs saints. All are called to holiness, and holy people alone can renew humanity. Many have gone before us along this path

Frassati, Spiritual Book Association, 1960; Luciana Frassati, Piergiorgio Frassati, I giorni della sua vita, Studium-Roma, 2011.

${ }^{2}$ Sfântul inchisorilor, ed. monahul Moise, Alba Iulia, Reîntregirea, 2007; Ioan Ianolide, Întoarcerea la Hristos, București, Christiana, 2006; Fabian Seiche, Martiri şi mărturisitori români din secolul XX. Inchisorile comuniste din România, Făgăraș, Agaton, 2014, p. 232-242. 
of Gospel heroism, and I urge you to turn often to them to pray for their intercession"3. Both of the characters we deal with are representative examples of Christian witness that communicated a deep spiritual experience to the young people.

What makes Pier Giorgio Frassati so unique and special? He was simply a young man who was in love with his family and friends, in love with the mountains and the sea, but especially in love with God. His way of life probably exceeded the average level of contemporaries, reaching a level that today, marked by increasing welfare and the spread of science and technology, is accessible to all. Pier Giorgio was not a typical young man for his time, he is much more similar to the youngers of today: he enjoyed to go to mountains, to do sports, drive a car, use the phone, admiring the paintings, to love music, going to university, traveling to Italy or abroad. Thanks to father's profession, he was aware of the contemporary history and dynamic of life in foreign countries, for his time unusual opportunities, while today ordinary. Therefore Pier Giorgio had to face the "new things" that today are normal and was forced to find solutions that constantly provoke a Christian conscience.

Great unifying force that expressed by his faith was like a magnet for contemporary youngers. He was a young man who had no obscure zones, no inner divisions, had a strong attitude in the face of life's difficulties, stirred, but not shaken in suffering, being aware that suffering is necessary to avoid giving up to any characteristic of his humanity, but enjoying it in full and complete chastity.

He was born in Turin on April 6, 1901, in a family not quite among the fervent faithful of the Church, his father, Alfredo Frassati, being a declared agnostic, director of the liberal newspaper "La Stampa" and politician too, in a certain period Ambassador in

${ }^{3}$ Message of the Holy Father John Paul II to the Youth of the World on the occasion of the $20^{\text {th }}$ World Youth Day (Cologne, August, 2005) cf http://w2.vatican.va/content/john-paul-ii/en/messages/youth/documents/hf_jpii_mes_20040806_xx-world-youth-day.html, 22 March 2016. 
Germany, and his mother, Adelaide Ametis, a well-known liberal painter.

In 1918 he enters the Society of St. Paul de Vincent and there he dedicates to serving the poor and the disadvantaged. He decides to become a mining engineer to serve Christ among those who were working in mines. A communicative and slightly ironic spirit among his friends, he was perceived as a ferment of excitement, he managed to coalesce around him students from various faculties. The academic study, coupled with an active presence in the social space and an intense sporting activity, represented the three dimensions of his daily life, built on the principle of fervent faith, described as an act of defence of spiritual heritage and the fight for eternal truth.

Although he considered his studies his first duty, they did not keep him from social and political activism. In 1919, he joined the Catholic Student Foundation and the organization known as Catholic Action. He became a very active member of the People's Party, which promoted the Catholic Church's social teaching based on the principles of Pope Leo XIII's encyclical letter "Rerum Novarum". On this occasion he publicized an active principle of Christian spirituality - Christian love must be accompanied by a social reform.

Three years later he joined the Dominican Order of lay people, taking the name Girolamo after the hero and his model for a long time, a famous missionary and preacher - Girolamo Savonarola. If someone wanted to congratulate him for his new name, he used to reply: "If I might be able to emulate his virtue and struggle!"

At the same time, he was also an active sportsman and he was always in the centre of the student activities. He loved the mountains and practiced climbing. Therefore its spirituality was conditioned by what he used to call "the gaze to the heights", given by the experience of climbing the peaks. Although his protector was a preacher, Pier Giorgio was not a witness from the pulpit, but by his inner life, accompanied by his native generosity and natural good humour and kindness that made his presence known and offered him a persuasive seductive power for those around it. The spiritual resource for such life was his special devotion to the Eucharist, attending daily Mass, with a preparation period followed by a time 
dedicated to liturgical meditation. The practise of sports was conditioned by the participation to Mass. Both the church liturgy and the liturgy of creation had the same purpose - to raise the eyes to a different reality, where to admire the greatness of God.

He was called "the man of the eight beatitudes", for he embodied in his daily life, without anything spectacular, Christ's spirit of Christian happiness. This is the legacy we have from him. Related to humility, Pier Giorgio affirms that the faith received in baptism ${ }^{4}$ suggests that by ourselves we can do nothing; but if we have God at the centre of our actions, one may reach the goals. An awareness of the vulnerability without God is followed by a life full of renunciation and sacrifice (longing after God), before the eternal joy of heaven. Meekness represents a solution to the violent and hateful world. Love and peace of Christ stand at the very base of a brotherhood preached by the gospel of Christ. Thirst for justice is interpreted by Pier Giorgio as serving others with our own resources. This determines our soul's health. Mercy manifested in the ministry of the brother is a proof that the love of Christ dwells in us and the way Christian vocation is visibly manifested. Purity of heart places us before God, becoming his close associates on earth. The friendship that he has practiced was constructed on a peaceful approach generated by the spreading of Christ's peace in the world. Finally, since we embark on the way to the Kingdom, struggle for truth and keeping a spiritual heritage make the difference between life and survival. He who wants to "live" and not just to "survive" prepares his soul for the struggle. At the end of the road one can speak about a healthy spiritual society, generated by a moral and ascetic exercise and constant prayer.

When he was only 24 years old, Pier Giorgio gets a poliomyelitis, that will cause death soon after. At his funeral the streets were filled with people whom he served more than seven years, as a consecration of his mission on earth and, consequently, as a confirmation of the holiness of his life in all its concreteness.

\footnotetext{
${ }^{4}$ Luciana Frassati, Piergiorgio Frassati, I giorni della sua vita, Studium-Roma, 2011, p. 121.
} 
Regarding his mission among young people, a very suggestive intervention of him before a Youth Meeting can be evidently used as a program. I will quote it at large:

„In this trying time that our country is going through, we Catholics, and especially we students, have a serious duty to fulfil: our self-formation. We (...) must steel ourselves for the battle we shall certainly have to fight to fulfil our programme and give our country, in the not too distant future, happier days and a morally healthy society. But to achieve this we need constant prayer to obtain from God the grace without which all our powers are useless; organisation and discipline to be ready for action at the right time; and finally, the sacrifice of our passion and of ourselves, because without that we cannot achieve our aim".

One can clearly identify in this text some pillars for the renewal and transformation of the contemporary society by the means of the young people action. Firstly it is quite necessary a selfformation, interpreted as education as well as moral observance of the Christian commandments. This is considered as a program that, one fulfilled, will bring tranquil days and a moral prosperity of the surrounding world. And next to this he adds the necessity of constant prayer, as means for achieving the divine grace, the necessary fuel for any social endeavour. By his manifest goes along with the confirmed tradition of the Church that establishes a primate of the personal transformation before the transformation and improvement of the world itself. He was involved a lot in social movements, but only as a result of a very constant and serious inner purification. Pope John Paul II in the sermon dedicated to Pier Giorgio on the occasion of his beatification on May 28, 1990, clearly highlights this symbiosis between inner life and social service that made him a missionary and an example for the young people of the $20^{\text {th }}$ century. I will quote a suggestive paragraph:

${ }^{5}$ From a speech to the Catholic Youth of the Millets Marie circle, 30.X.1922. 
„Therefore the words of the Apostle Peter are addressed not only to the people of his day, but also to all of us and our contemporaries. "Sanctify Christ as Lord in your hearts. Always be ready to give an explanation to anyone who asks you for a reason for your hope" (1 Peter 3:15). In our century, Pier Giorgio Frassati... incarnated these words of St. Peter in his own life. The power of the Spirit of Truth, united to Christ, made him a modern witness to the hope which springs from the Gospel and to the grace of salvation which works in human hearts. Thus he became a living witness and courageous defender of this hope in the name of Christian youth of the twentieth century"

In this frame one can identify two main driving force of his existence - faith and charity that made him an active and diligent missionary, a joyful and enthusiastic apostle of Christ, in the milieu he spent his life, his family and school. In the next lines of the Pope's homily, one may clearly identifiy some spiritual constants that represented the pillars of his missionary activity: ascetical life and purity, faith and sacrifice (accepting also life's difficulties), Eucharist and service, simplicity of life and a deep friendship and, finally, a call to action.

I will quote now some suggestive fragments corresponding to these five pillars of his missionary activity among young people, so that to argue the idea expressed above. I will use later the same pattern in the case of Valeriu Gafencu so that to further argue the theological idea that one may identify some concrete spiritual constants in the life of the people who struggled to achieve holiness, contributing to what we call "spiritual ecumenism"".

${ }^{6}$ L'Osservatore Romano, Weekly Edition in English, 28 May 1990, p. 9; for the Italian text see https://w2.vatican.va/content/john-paulii/it/homilies/1990/documents/hf_jp-ii_hom_19900520_beatificaz-frassati.html. 7 Regarding this concept, Vatican II Council puts spirituality in the heart of ecumenism and sees no valid ecumenism out of it: "There can be no ecumenism worthy of the name without a change of heart. For it is from renewal of the inner life of our minds, from self-denial and an unstinted love that desires of unity take their rise and develop in a mature way. We should therefore pray to the Holy Spirit for the grace to be genuinely self-denying, humble, gentle in the service of others, and to have an attitude of brotherly generosity towards them. This change of heart and holi- 


\section{PILLARS OF MISSIONARY ACTIVITY \\ Pier Giorgio Frassati}

ness of life, along with public and private prayer for the unity of Christians, should be regarded as the soul of the whole ecumenical movement, (emphasis my own) and merits the name, 'spiritual ecumenism'." (Unitatis Redintegratio, §§ 7-8); Cardinal Joseph Ratzinger (Pope Benedict XVI) clearly states that ecumenism reduced to doctrinal issues is an incomplete way of doing ecumenical theology: "Logically, a unity negotiated by the people couldn't be more than a juris humani. It doesn't express the theological unity described in John 17. It couldn't be a witness of the Mystery of Jesus Christ, but only reflects the diplomatic ability and capacity of doing compromises of the negotiators. This is not negligible, but has nothing to do with the religious level, the only essential for ecumenism. The declarations of theological consensus necessarily dwell on the human intellect and create the faith act's conditions, but they are not really concerned with the act of faith. It seems to me that it is really important to recognise the limitation of the negotiation ecumenism, in order not to hope more than it can really give..." Furthermore, he sees the solution in adopting "a power of religious origin" which is spirituality (Eglise, Ecuménisme et Politique, Paris, Fayard, 1987, p. 145, 187); Cardinal Walter Kasper, head of the Vatican office responsible for promoting Christian unity, goes along with this very idea when, in his booklet, $A$ Handbook of Spiritual Ecumenism, formulates, in 2007, a principle of all genuine spiritual ecumenism: "Each time we engage in common prayer, each act of common witness, indeed every act of spiritual communion is a gift of the Holy Spirit who binds us together and enables us to give visible expression to our Lord's desire for unity.", $A$ Handbook of Spiritual Ecumenism, New City Press NY, 2007, Preface, 3b). From the Orthodox side, one of the well-known voices in the Ecumenical Movement, Father Ion Bria broadens this idea, in the sense he asserts that spirituality can bring us together and the saints of the Church can be the promoters, in the most valid sense, of Christian unity: "Everyone has the freedom and grace to become his disciple, to contribute to a community of saints. It is in this spiritual combat for holiness in their life that Christian can reach a deeper level of unity. There is already a communion among the saints", "A fresh breath of spirituality", Ecumenical Review, 44, 4 (1992), p. 431-2. Similarly, Metropolitan John Zizioulas emphasizes that: "Praying for holiness must go together with working for unity." (Canberra Assembly, 1991, cf. Ion Bria, art. cit., p. 431). See also André Borrély; Max Eutizi, L'œecuménisme_spirituel, Genève, Labor et Fides, 1988. Lastly, the protestant theologian Egon W. Gerdes, in the same line, manifests a great optimism when speaking about the role of spiritual theology in ecumenism: spirituality "will do away with many misunderstandings."/ "Ecumenism and spirituality: a Protestant perspective, Theological Studies, 29, 1 (1968), p. 36. 


\begin{tabular}{|c|c|}
\hline $\begin{array}{l}\text { Ascetical life and } \\
\text { purity }\end{array}$ & $\begin{array}{l}\text { In order to keep his purity, it took many hours of } \\
\text { fierce and laborious struggle, which nobody knew } \\
\text { about, except for a few close friends. Here is what } \\
\text { one of them wrote: These struggles, which were } \\
\text { imprinted upon the physical character of our friend, } \\
\text { lasted quite a while and required of him an energy } \\
\text { of exceptional quality. He scrupulously controlled } \\
\text { his actions in order to multiply his austerities and } \\
\text { avoid occasions which could have shaken his } \\
\text { resolutions. The words of Saint Paul fitted him quite } \\
\text { well: 'I have fought the good fight'. }\end{array}$ \\
\hline $\begin{array}{l}\text { Faith and sacrifice } \\
\text { Faith - base for } \\
\text { existence; putting God } \\
\text { in the centre of life; }\end{array}$ & $\begin{array}{l}\text { To live without faith, without a patrimony to defend, } \\
\text { without a steady struggle for truth, that is not } \\
\text { living, but existing... The faith given to me in } \\
\text { baptism suggests to me surely: by yourself you will } \\
\text { do nothing, but if you have God as the centre of all } \\
\text { your action, then you will reach the goal. } \\
\text { Our life so that to be Christian is a continual } \\
\text { renunciation, an endless sacrifice, which is, in fact, } \\
\text { not very heavy, if one thinks that these years } \\
\text { accompanied by pain are less that the happy } \\
\text { eternity, where the joy won't have limit and end, } \\
\text { where we will achieve an unimaginable peace. We } \\
\text { have to stay close to faith, what would have been } \\
\text { our life without it? Nothing, would have been spent } \\
\text { in vain } 9 \text {. }\end{array}$ \\
\hline $\begin{array}{l}\text { Eucharist and service } \\
\text { - source for a tripartite } \\
\text { apostleship: example, } \\
\text { charity, persuasion; } \\
\text { Eucharist is prolonged } \\
\text { in the service of the } \\
\text { poor. }\end{array}$ & $\begin{array}{l}\text { Jesus comes to me every morning in Holy } \\
\text { Communion: I repay him in my very small way by } \\
\text { visiting the poor. } \\
\text { With all the strength of my soul I urge you young } \\
\text { people to approach the Communion table as often } \\
\text { as you can. Feed on this bread of the angels whence } \\
\text { you will draw all the energy you need to fight inner } \\
\text { battles }{ }^{10} \text { (...) And when you are consumed by the } \\
\text { Eucharistic fire, you will be able to thank the Lord } \\
\text { God with even more recognition, you who are } \\
\text { called to be a member of His flock; will receive a }\end{array}$ \\
\hline
\end{tabular}

\footnotetext{
${ }^{8}$ Luciana Frassati, Piergiorgio Frassati, I giorni della sua vita, p. 121.

${ }^{9}$ Luciana Frassati, Piergiorgio Frassati, p. 121.

${ }^{10}$ Luciana Frassati, Piergiorgio Frassati, p. 121.
} 


\begin{tabular}{|l|l|}
\hline peace that those who are happy according to the \\
world have never tasted. Because real happiness, \\
young people, does not consist of the pleasures of \\
the world and the realities of the earth, but in the \\
peace of conscience that we have only if we have a \\
heart that is pure and in the spirit. \\
Having fortified our spirit, we will start our \\
apostleship. And here we are speaking about three \\
apostleship. First by example, then by charity going \\
amongst those who are grieved and comforting \\
them, because the Catholic religion is based on \\
charity, which is nothing else than perfect love. St. \\
Paul says: 'The charity of Christ urges us'. Without \\
such fire, which day by day has to destroy our \\
personality and blaze only for other people's \\
suffering, we would not be Christian's, let alone \\
Catholics. \\
Finally the apostleship of persuasion, which is the \\
most beautiful and necessary. Go to your work- \\
mates, who are estranged from the Church and who \\
spend their free time in unhealthy pursuit, persuade \\
them to follow God's paths, so full of thorns but so \\
full of roses as well. (from a speech to Catholic \\
Youth of Pollone, 29.VI.1923)
\end{tabular}




\begin{tabular}{|l|l|}
\hline Joyful life & $\begin{array}{l}\text { angels in the cave to be the Saviour of humanity } \\
\text { (...) I also thank you for the prayers which are the } \\
\text { best possible sign of friendship }\end{array}$ \\
\hline $\begin{array}{l}\text { You ask me whether I am in good spirits. How } \\
\text { could I not be, so long as my trust in God gives me } \\
\text { strength! We must always be cheerful. Sadness } \\
\text { should be banished from all Christian souls. For } \\
\text { suffering is a far different thing from sadness, } \\
\text { which is the worst disease of all. It is almost always } \\
\text { caused by lack of Faith. But the purpose for which } \\
\text { we have been created shows us the path along } \\
\text { which we should go, perhaps strewn with many } \\
\text { thorns, but not a sad path. Even in the midst of } \\
\text { intense suffering it is one of joy. }\end{array}$ \\
$\begin{array}{l}\text { "Verso l'alto!" "To the top!" He used to say this } \\
\text { while hiking with his friends, instructing them: } \\
\text { "The higher we go, the better we shall see the face } \\
\text { of Christ! If you have God at the centre of your } \\
\text { action, then you will reach the goal." } \\
\text { "Go! Get up! Act!... You who are poor in spirit, go! } \\
\text { Get up, do something! Yours is the Kingdom of } \\
\text { Heaven!" }\end{array}$ \\
\hline
\end{tabular}

\section{Valeriu Gafencu - a young missionary spirit in the Romanian communist prisons}

Regarding the second character in discussion, Valeriu Gafencu, he is one of the most well-known contemporary Romanian young missionary, called by Nicolae Steinhardt "the saint of prisons" ${ }^{\prime 2}$. His name is strongly connected with the Christians' terrible suffering during communist regime in Romania and the power of witnessing up to their death.

Devoting themselves to the prayer of Jesus, studying and learning texts from the Holy Scripture, the Philokalia, and other patristic writings, the Communist prisoners were to form a philocalic

${ }^{11}$ Luciana Frassati, Piergiorgio Frassati, p. 123.

${ }^{12}$ Cf. Jurnalul fericirii, Cluj-Napoca, Dacia, 1992, p. 133. 
way of life. United in their desire to sacrifice themselves for Christ, these monks in spirit supported each other, preparing themselves for the difficult trials which were yet to come. To underline this idea, I will quote one of the very important names around this period, Virgil Maxim. He asserts: "Your cell became a sanctuary of prayer, of nourishment, an opportunity for ascesis, solitude, renunciation of the material goods and joys of life, an opportunity to live as paupers, in purity and chastity. The chronic uncertainty of our situation enabled us to put our trust in the will and providence of God. Obedience requires a superior - a father confessor... - to whom one submits, and God also offered us this gift through the presence of our priests. We were also obedient to the program imposed by worldly authority, as an act of divine pedagogy, in which your will enters consciously in submission to the divine will" ${ }^{\prime 13}$.

In the same line, I will quote another important voice for this period, while referring to that very specific context in terms of missionary activity. Looking back on these long and hard years of imprisonment, Father Arsenie Papacioc sees them as a blessed opportunity for strengthening his faith: "There were no other means of preparation that could offer such possibilities for growing in one's faith, for a spiritual deepening, for a living relationship with God as were offered by the tribulations of imprisonment. I bless that period of time. I spent years in the wilderness without coming upon the possibility to deepen my thoughts of eternity, of the divine nature; this possibility was accorded me by way of the torturous dailiness [of life in a Communist prison]. Suffering also united us. Those of us who succeeded in knowing each other on the cross, so to speak, remained united"14.

Similar with Giorgio Frassati, Valeriu Gafencu was a man of beatitudes, despite the completely different context of living, in a state of terrible suffering. Virgil Ioanid remembers how, on the road between two prisons, in a police van, laid low by tuberculosis,

\footnotetext{
${ }^{13}$ Imn pentru crucea purtată, Antim, București, 2002, p. 117.

${ }^{14}$ Cf. Sfântul închisorilor, ed. monahul Moise, Alba Iulia, Reîntregirea, 2007, p. $45-46$.
} 
Valeriu spoke of "the happiness of suffering for Christ and of enduring, like the first martyrs, the persecution unleashed by the enemies of the faith". Likewise, in a letter sent to his family, he confessed, "Today I am happy. Through Christ I love everyone"15.

Now I am going to point to some biographical information regarding his spiritual itinerary. He was born on 24 January 1921, in Sângerei town, Bălți County, Bessarabia, and he passed away on 18 February 1952, in the prison of Târgu Ocna. He attended the primary school at Sângerei and continued his education at "Ion Creanga" Highschool in Bălți, during 1932-1940. Just few days after graduating high school, the summer of 1940, intervened the Soviet occupation. Valeriu barely managed to cross Prut River, and he arrived in Iasi, leaving his parents and sisters in the occupied territory. He did not know that this separation from his father was definitively, who, in the autumn of that very year, was taken to Siberia and he ended his life somewhere there. Soon he attended the courses of the Faculty of Law and Philosophy in Iasi. Because of his implication in the Legionary organisation of the Brotherhood of the Cross organization was arrested by Antonescu Regime as well as by the Communist Militia. Thus, he spent several years in different prisons, as Aiud (1941-1949), Pitesti (November-December 1949) and Târgu Ocna (1949-1952), where he became a profound orthodox witness. He confesses that the regime's harsh detention, the torture and diseases contacted there strengthened his faith. In 1949 he was taken to the sanatorium-prison in Târgu Ocna in a serious condition of illness: bones' and rheumatic tuberculosis.

On February 2, 1952, he urged his colleagues of suffering to procure a candle, a crucifix and a white shirt so that to prepare them for the day of his passing away. The day before his death, he said to Ioan Ianolide: "Tomorrow I will die. I want to say goodbye to my closest friends. Do so they silently come on line to me". On the next day, February 18, around 2-3 p.m., Valeriu Gafencu expressed his last words: "Lord, give me the slavery that frees the soul and take from me the freedom that winds my soul", and then he passed away.

${ }^{15}$ Sfântul închisorilor, p. 296. 
The spiritual path he proposes to us and especially to young people is concentrated on inner purification and self-knowledge, within a liturgical context, similar with Frassati, as a result of personal experience of God-Himself. I will quote a fragment where one may find a kind of programmatic manifest and a missionary prospective:

"Through baptism, we received purifying grace, while being anointed with Holy Chrism, we have been adorned with all the gifts of the Holy Spirit. But this blessed internal state is ineffective within us, we are Christians in name only. We live in a world of confusion, of loose morals, of sin. It's considered shameful to be a believer, and oldfashioned to be moral. The baptized man, in order to be saved, has to live all his life in the Holy Spirit, but we haven't succeeded in doing this. We have believed, we have prayed, we have kept the faith, we have suffered, but in order to be united with Christ, one must purify oneself inwardly through confession and renew oneself through Holy Communion. Therefore unite yourself to Christ conscientiously and with great steadfastness, making yourself a bearer of His holiness, His power, His love, His light, His immortality. You must oppose sin mercilessly. Then you will be born anew. There is no path of compromise" $"$.

One may find in this text the main pillars necessary for the renewal and transformation of the contemporary society by the means of the young people action. Firstly it is quite necessary to have an active spiritual life ${ }^{17}$ that makes present the baptismal gifts in a

\footnotetext{
${ }^{16}$ Sfântul închisorilor, p. 138.
}

17 It is worth mentioning his climax in matter of spiritual experience - the receiving of the divine grace - that one easily may compare with the spiritual experience of the ancient Father of the Church. After a time of much uneasiness, after experiencing a great deal of pain, when the cup of suffering had filled up, there came a holy day, in June 1943, when I fell to the ground, on my knees, my head bent, my heart shattered, in a burst of tears. I prayed to God that He grant me light. At that point I had lost all faith in people. I realized perfectly well that I was in truth, but then why was I suffering? Within my zealous soul only love had remained. No one understood me. During this long period of weeping I began to do prostrations. And suddenly - O Lord! How great art thou, Lord! - I saw my soul full of sins, I found within myself the root of all the sins of mankind. Alas, so many sins, and the eyes of my soul, 
virtuous life. He calls this "rebirth" by the means of inner purification and confession, on one hand, and by partaking of the Holy Communion, on the other hand. The supporters of this process are a strong faith, a permanent prayer and the avoidance of sin. This might be considered as a program that, one fulfilled, will bring in the world Christ's holiness, power, love and light and, finally, His gift of immortality. One still needs for that a determination and a piety, without any compromise. Like in the case of Frassati, Gafencu establishes a primate of the personal transformation before the transformation and improvement of the world itself. He was involved in the spiritual process of the transformation of those surrounding him, but only as a result of a very constant and serious inner purification.

I will try now to identify Gafencu's spiritual pillars, using the same pattern evoked above with reference to Frassati's personality.

\begin{tabular}{|l|l|}
\hline $\begin{array}{l}\text { PILLARS OF } \\
\text { MISSIONARY } \\
\text { ACTIVITY }\end{array}$ & Quotation \\
\hline $\begin{array}{l}\text { Ascetical life and } \\
\text { purity }\end{array}$ & $\begin{array}{l}\text { During this long period of weeping I began to do } \\
\text { prostrations. And suddenly - O Lord! How great } \\
\text { art thou, Lord! - I saw my soul full of sins, I found } \\
\text { within myself the root of all the sins of mankind. } \\
\text { Alas, so many sins, and the eyes of my soul, } \\
\text { hardened by pride, had not seen them. How great is }\end{array}$ \\
\hline
\end{tabular}

hardened by pride, had not seen them. How great is God! Seeing all my sins, I felt the need to shout them forth and cast them away from me. And a deep peace, a deep wave of light and love poured into my heart. As soon as the door opened, I left my cell and went to those whom I knew to love me and to those who hated me and to those who had most wronged me and I confessed to them openly, 'I am the most sinful man. I do not deserve the trust of even the last among men. I am blessed!' Everyone was astounded. Some looked at me with disdain, others with indifference. Some looked at me with a love that they themselves could not have explained. A single person said to me, 'You deserve to be kissed.' But I fled quickly back to my cell, threw my head into my pillow and continued my weeping, thanking and glorifying God (cf. Ioan Ianolide, Întoarcerea la Hristos, p. 231-232; see also Sfântul închisorilor, p. 66-67). 


\begin{tabular}{|c|c|}
\hline & $\begin{array}{l}\text { God! Seeing all my sins, I felt the need to shout } \\
\text { them forth and cast them away from me. And a deep } \\
\text { peace, a deep wave of light and love poured into my } \\
\text { heart. As soon as the door opened, I left my cell and } \\
\text { went to those whom I knew to love me and to those } \\
\text { who hated me and to those who had most wronged } \\
\text { me and I confessed to them openly, 'I am the most } \\
\text { sinful man. I do not deserve the trust of even the } \\
\text { last among men. I am blessed! }\end{array}$ \\
\hline Faith and sacrifice & $\begin{array}{l}\text { Virgil Ioanid remembers how, on the road between } \\
\text { two prisons, in a police van, laid low by } \\
\text { tuberculosis, his cheeks bright red with fever, } \\
\text { Valeriu spoke of the happiness of suffering for } \\
\text { Christ and of enduring, like the first martyrs, the } \\
\text { persecution unleashed by the enemies of the faith. } \\
\text { Likewise, in a letter sent to his family, he } \\
\text { confessed, Today I am happy. Through Christ I love } \\
\text { everyone. } \\
\text { I leave now the world... I will remain a faithful } \\
\text { soldier of the Church for in this time Jesus must } \\
\text { have been in prison. I tremble and happy in the } \\
\text { same time that one offers me the possibility to die } \\
\text { for Him. Do not abandon the Church... Christianity } \\
\text { has new martyrs and with them a new breath comes } \\
\text { out... } 19\end{array}$ \\
\hline $\begin{array}{l}\text { Eucharist and } \\
\text { service }\end{array}$ & $\begin{array}{l}\text { The baptized man, in order to be saved, has to live } \\
\text { all his life in the Holy Spirit, but we haven't } \\
\text { succeeded in doing this. We have believed, we have } \\
\text { prayed, we have kept the faith, we have suffered, } \\
\text { but in order to be united with Christ, one must } \\
\text { purify oneself inwardly through confession and } \\
\text { renew oneself through Holy Communion. Therefore } \\
\text { unite yourself to Christ conscientiously and with } \\
\text { great steadfastness, making yourself a bearer of His } \\
\text { holiness, His power, His love, His light, His } \\
\text { immortality }{ }^{20} \text {. }\end{array}$ \\
\hline
\end{tabular}

${ }^{18}$ Ioan Ianolide, Intoarcerea la Hristos, p. 231-232.

${ }^{19}$ Sfântul închisorilor, p. 279.

${ }^{20}$ Sfântul închisorilor, p. 138. 


\begin{tabular}{|l|l|}
\hline $\begin{array}{l}\text { Simplicity of life and } \\
\text { deep friendship }\end{array}$ & $\begin{array}{l}\text { I see all the people with the same love, despite the } \\
\text { fact to some of them I bring compliments, regarding } \\
\text { others I feel pity and sorrow, trembling while } \\
\text { thinking what is going to happen with them. I } \\
\text { forgive with all my soul freedom those who } \\
\text { produced a lot of evil things. In fact, those who } \\
\text { fought against me strongly pushed me in the arms } \\
\text { of the Lord and I thank them very much. I pray for } \\
\text { my friends, for Christians and for the salvation by } \\
\text { the lith hour of my enemies }{ }^{21}\end{array}$ \\
\hline $\begin{array}{ll}\text { Jvery true joy is gained with the high price of } \\
\text { sacrifice. Every citadel is conquered by the means } \\
\text { of faith, courage, audacity and confidence in the } \\
\text { mission given by God and, especially, by prayer... I } \\
\text { would like to let you know that I consider these } \\
\text { times and I see them as a state of expiation: with a } \\
\text { limpid soul and peacefulness, with a mysterious joy } \\
\text { and a great hope. I would like you to know that I } \\
\text { am happy. These times are the confirmation of my } \\
\text { path I have witnessed long time ago. This joy is so } \\
\text { deep so that I can look to death with inner } \\
\text { acceptance and with the hope of the future } \\
\text { happiness } 22\end{array}$ \\
$\begin{array}{ll}\text { Christians propose to the world a spirituality and } \\
\text { the world must struggle to find the forms of life } \\
\text { pertaining to this in the contemporary times. The } \\
\text { construction of the world on the base of faith } \\
\text { represents a profound refreshment of the Gospel. } \\
\text { The apostolic and martyrical spirit must remain } \\
\text { alive. The pure and holy aspirations must } \\
\text { continuously reverberate in the world. We long for } \\
\text { a Christian world, consummated by the fire of faith } \\
\text { and love, while going towards the passions and } \\
\text { martyrdom, and glorifying the resurrection, the } \\
\text { transfiguration and the ascension. } \\
\text { He speaks about ten principles for renewing } \\
\text { Christian life, in general, and of the youngers, in } \\
\text { particular: the principle of love, of soul's honour, of }\end{array}$ \\
\hline Call to action
\end{tabular}

${ }^{21}$ Sfântul închisorilor, p. 278-279.

${ }^{22}$ Sfântul închisorilor, p. 298. 


\begin{tabular}{|l|l|}
\hline & $\begin{array}{l}\text { education, of prayer, of unity, of obedience, of } \\
\text { freedom, of ecumenical advice, of community, of } \\
\text { soul's ablution, of the permanent sacrifice and of } \\
\text { knowledge. Finally, he admonishes: Love Christ } \\
\text { and you will be happy! }{ }^{23}\end{array}$ \\
\hline
\end{tabular}

\section{Conclusion}

What is impressing in the case of the two contemporary young missionaries is their purity, radiant joy, piety and freedom as children of God for all that is beautiful in the world. And, in consequence, one can highlight their social conscience, the awareness they had of sharing the life and destiny of the Church and this occurs in a time when purity, piety, and faithfulness to the Church are treated disparagingly and viewed as out-dated.

This methodology of paradigms highlights a tripartite stage itinerary. Firstly, both of them show that a missionary life in not possible out of an ascetic struggle of purification. This is, in consequence, developed within ecclesiastic border, observing the ancient rule - there is no spiritual life un-ascetical as well as non-ecclesial. And finally, a third important aspect of their mission points to a salient element, regarding witnessing Christian life. Both of them, while doing missionary activity communicated a personal experience that invites and seduces young generation. They have a strong and clear message for the contemporary young generation: Get up, do something! Yours is the Kingdom of Heaven! (Frassati) and Love Christ and you will be happy! (Gafencu)

${ }^{23}$ Sfântul închisorilor, p. 256-259. 